\title{
Characteristics of Formaldehyde Emission from Indoor Crib
}

\author{
Huimin DONG \\ School of Civil Engineering \\ Henan Polytechnic University \\ Jiaozuo, Henan, 454000, China \\ e-mail: 418641725@qq.com
}

\author{
Gaowei YUE \\ School of Civil Engineering \\ Henan Polytechnic University \\ Jiaozuo, Henan, 454000, China \\ e-mail: mxlygw@163.com
}

\author{
Minmin LI \\ School of Civil Engineering \\ Henan Polytechnic University \\ Jiaozuo, Henan, 454000, China \\ e-mail: 1352537846@qq.com
}

\begin{abstract}
Based on characteristics of wood crib releasing formaldehyde $\left(\mathrm{CH}_{2} \mathrm{O}\right)$, a physical model, which $\mathrm{CH}_{2} \mathrm{O}$ releases and diffuses from crib in indoor, is established to simulate the distribution characteristics of $\mathrm{CH}_{2} \mathrm{O}$ concentration in confined and ventilated indoor. $\mathrm{CH}_{2} \mathrm{O}$ concentration near crib is larger, and then gradually reduced to around. When baby lies down, sits and stands in crib interior, $\mathrm{CH}_{2} \mathrm{O}$ concentration decreased with height increasing. Compared $\mathrm{CH}_{2} \mathrm{O}$ concentration in confined indoor, $\mathrm{CH}_{2} \mathrm{O}$ diffusion is strengthened with indoor ventilation, and $\mathrm{CH}_{2} \mathrm{O}$ concentration in crib interior is decreased at different height, especially in the middle part decreases obviously.
\end{abstract}

Keywords-formaldehyde; crib; indoor pollution; ventilation

\section{INTRODUCTION}

With the improvement of socio-economic level, for comfortable living environment, furniture aesthetics become increasingly demanding, but the resulting indoor air pollution has become increasingly serious [1]. Seen from related investigations, decoration materials paint, wallpaper, plywood, lots of applications, $\mathrm{CH}_{2} \mathrm{O}$ exceeding rate of $60 \%$ to $100 \%$ in newly renovated public spaces, and $\mathrm{CH}_{2} \mathrm{O}$ having 3 to 15 years of long release cycle. This makes $\mathrm{CH}_{2} \mathrm{O}$ has become an indication of indoor pollution contaminants [2]. However, the infant indoor $\mathrm{CH}_{2} \mathrm{O}$ pollution is particularly prominent. $\mathrm{CH}_{2} \mathrm{O}$ have different degrees of stimulation damaging effect respiratory system, nervous system and immune system [2-3]. IARC has confirmed human carcinogen $\mathrm{CH}_{2} \mathrm{O}$, these indoor pollutants associated with $70 \%$ of human disease, exceeding $90 \%$ of children are contaminated by interior of leukemia gas caused [4-5]. Because infants is sensitive populations, so more vulnerable to air pollutants, meanwhile children most of time is spent indoors. This will resulting increase incidence of various diseases indoor air pollution exposure has long, low-dose characteristics, Research shows that infant respiratory system, heart and lung function, asthma and serious harm to the immune system caused by $\mathrm{CH}_{2} \mathrm{O}$ pollution [6].
Currently, parents increasing emphasis crib over issue of $\mathrm{CH}_{2} \mathrm{O}$ release, however, about crib release of $\mathrm{CH}_{2} \mathrm{O}$ has been reported rarely. By establishing crib $\mathrm{CH}_{2} \mathrm{O}$ release model, by analyzing effect of ventilation on reducing $\mathrm{CH}_{2} \mathrm{O}$ concentration, thus reducing the harm of $\mathrm{CH}_{2} \mathrm{O}$ pollution caused by infants.

\section{FORMALDEHYDE INDOOR AIR DIFFUSION THEORY}

\section{A. Turbulence Model}

Follow through stress modeled Laminar Flow stress, introduced Boussinesq hypothesis, by the turbulence caused stress can be expressed as:

$$
-\overline{u_{i} u_{j}}=v_{t}\left(\frac{\partial U_{i}}{\partial x_{j}}+\frac{\partial U_{j}}{\partial x_{i}}\right)-\frac{2}{3} \kappa \delta_{i j}
$$

Wherein, $v_{\mathrm{t}}$ is turbulent eddy viscosity coefficient; $\mathrm{k}$ is the turbulent kinetic energy per unit mass of the fluid indicates the average kinetic energy of turbulent fluctuations; $U_{i}, u_{i}$, respectively represent the average amount and fluctuating volume velocity.

Three-dimensional unsteady N-S equation can be derived $k$ equation and $\varepsilon$ equation modeling after:

$$
\left\{\begin{array}{l}
\frac{\partial \kappa}{\partial t}+U_{j} \frac{\partial \kappa}{\partial x_{j}}=\frac{\partial}{\partial x_{j}}\left[\left(C_{\kappa} \frac{\kappa^{2}}{\varepsilon}+v\right) \frac{\partial \kappa}{\partial x_{j}}\right]-\overline{u_{i} u_{j}} \frac{\partial U_{i}}{\partial x_{j}}-\varepsilon \\
\frac{\partial \varepsilon}{\partial t}+U_{j} \frac{\partial \varepsilon}{\partial x_{j}}=\frac{\partial}{\partial x_{j}}\left[\left(C_{\varepsilon} \frac{\kappa^{2}}{\varepsilon}+v\right) \frac{\partial \varepsilon}{\partial x_{j}}\right]-C_{\varepsilon 1} \frac{\varepsilon}{\kappa} \overline{u_{i} u_{j}} \frac{\partial U_{i}}{\partial x_{j}}-C_{\varepsilon 2} \frac{\varepsilon^{2}}{\kappa}
\end{array}\right.
$$

When homogenized continuity equation, standard $k-\varepsilon$ two sides closed process control equations of the model is composed of $\mathrm{N}-\mathrm{S}$ equations and modeling of the $k$ equation and eddy viscosity coefficient $\varepsilon$ equation. 


\section{B. Release of Formaldehyde Diffusion Equation}

For crib wooden materials, $\mathrm{CH}_{2} \mathrm{O}$ will diffuse into indoor air, $\mathrm{CH}_{2} \mathrm{O}$ release strength is $0.01 \sim 0.015 \mathrm{kmol} /\left(\mathrm{m}^{2} . \mathrm{h}\right)$ [7], $\mathrm{CH}_{2} \mathrm{O}$ diffusion process can be expressed as:

$$
\frac{\partial \rho C}{\partial t}+\frac{\partial \rho C U_{j}}{\partial x_{j}}=\frac{\partial}{\partial x_{j}}\left(\frac{\mu}{\sigma C} \frac{\partial C}{\partial x_{j}}-\rho \overline{u_{j} C}\right)+S_{C}
$$

Where, $C$ is the concentration of formaldehyde, $S_{C}$ for the source term.

\section{CRIB FORMALDEHYDE DIFFUSION MODEL}

\section{A. Geometry}

A size of $4 \mathrm{~m} \times 6 \mathrm{~m} \times 3 \mathrm{~m}$ inside room (door size of $0.9 \mathrm{~m}$ $\times 2.1 \mathrm{~m}$, window size of $1.5 \mathrm{~m} \times 1 \mathrm{~m}$ ), place the size of $1 \mathrm{~m} \times$ $1.4 \mathrm{~m} \times 0.6 \mathrm{~m}$ cot (under section four wood leg support, high $0.4 \mathrm{M}$, wood pitch $3 \mathrm{~cm}$ bed four weeks), as shown in FIG. Crib placed in the room shown in Figure 1 (no other furniture indoor).

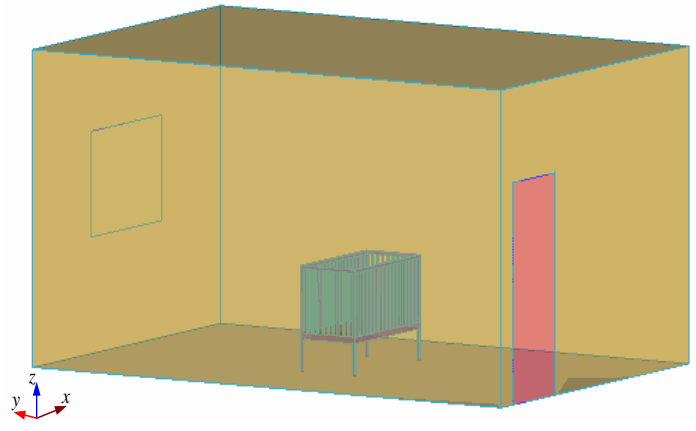

Figure 1. Crib model

\section{B. Physical Model}

(1) The use of multi-component transport model no chemical reaction to participate, the standard $\mathrm{k}-\varepsilon$ model and non-equilibrium wall function.

(2) Boundary conditions: formaldehyde releases from each board of crib.

\section{NumERICAL ANALYSIS OF FORMALDEHYDE RELEASE OF CRIB INDOOR}

This paper considers crib in closed and open doors and windows ventilation of indoor formaldehyde release under conditions. $\mathrm{CH}_{2} \mathrm{O}$ release in early crib, take this article formaldehyde emission intensity of $0.012 \mathrm{mmol} /\left(\mathrm{m}^{2} . \mathrm{h}\right)$, set the door when ventilation air inlet velocity, wind speed $1 \mathrm{~m} / \mathrm{s}$.

\section{A. Formaldehyde Concentration Distribution Indoor}

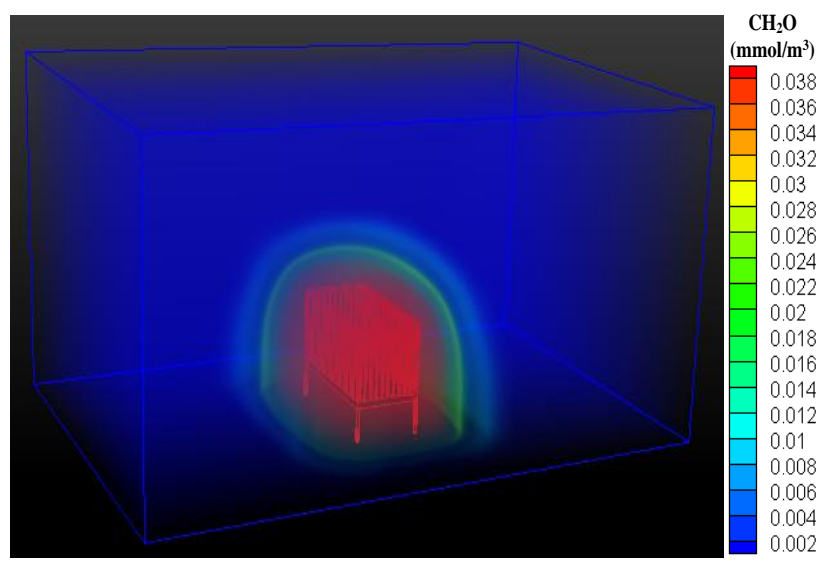

(a) Enclosed rooms

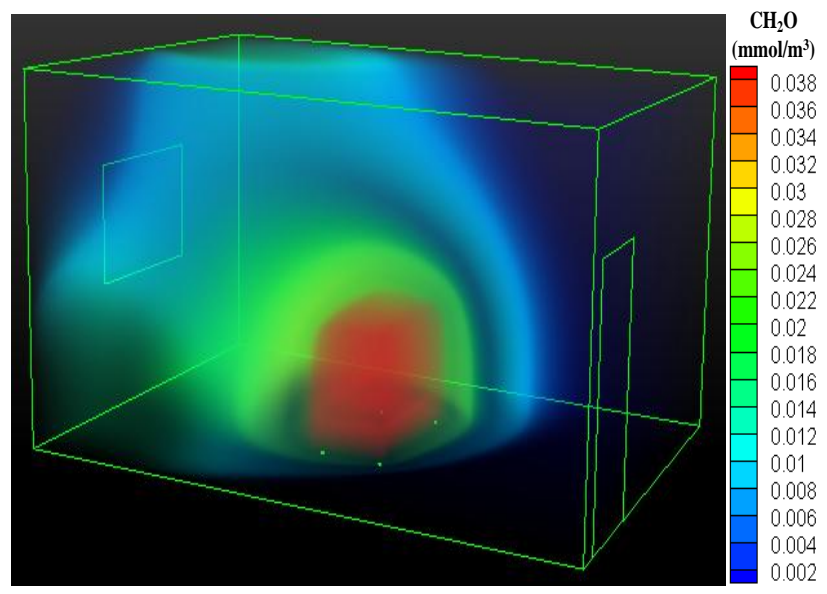

(b) Ventilate rooms

Figure 2. Formaldehyde concentration distribution indoor

From Fig. 2 it can be seen, because of crib surface is the release source of $\mathrm{CH}_{2} \mathrm{O}$, so that the $\mathrm{CH}_{2} \mathrm{O}$ concentration was highest of bed surface. enclosed room, the $\mathrm{CH}_{2} \mathrm{O}$ concentration gradually decreases from bed to surrounding, like the dome cover layer overlying crib around. When the air came from door, $\mathrm{CH}_{2} \mathrm{O}$ spread to window, resulting in the $\mathrm{CH}_{2} \mathrm{O}$ concentration reduced around the crib.

\section{B. Formaldehyde Concentration Distribution in Horizontal Plane}

Consider position height when baby lying(Facial height was $10 \mathrm{~cm}$ ), sitting (Facial height was $38 \mathrm{~cm}$ ) and standing(Facial height was $55.5 \mathrm{~cm})$ in crib, In model were $\mathrm{z}=0.56 \mathrm{~m}, \mathrm{z}=0.86 \mathrm{~m}$ and $\mathrm{z}=0.995 \mathrm{~m}$. Analysis of these three positions at height of $\mathrm{CH}_{2} \mathrm{O}$ concentration contours Distribution, as shown in Fig.3.

It can be seen from fig. 3, The higher region about $\mathrm{CH}_{2} \mathrm{O}$ concentration was near crib, and as position height increases when baby lying down, sitting and standing, $\mathrm{CH}_{2} \mathrm{O}$ concentration decreases. In closed room, $\mathrm{CH}_{2} \mathrm{O}$ diffusion capacity is weak, and therefore $\mathrm{CH}_{2} \mathrm{O}$ gathered around the crib, and $\mathrm{CH}_{2} \mathrm{O}$ concentrations is higher in inside space of bed. 


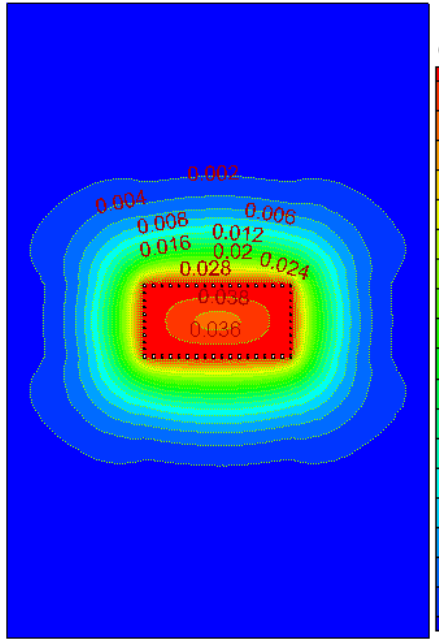

$\mathrm{CH}_{2} \mathrm{O}$ $\left(\mathbf{m m o l} / \mathbf{m}^{3}\right)$
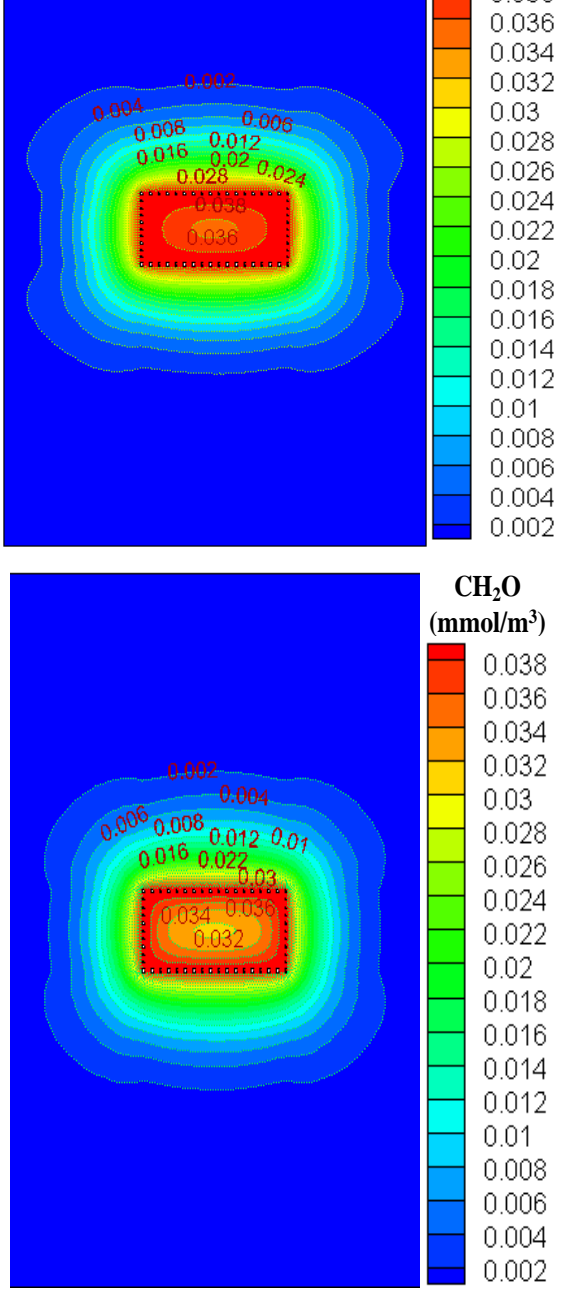

$\mathrm{CH}_{2} \mathrm{O}$

$\left(\mathrm{mmol} / \mathrm{m}^{3}\right)$

0.038

0.036

0.034

0.032

0.03

0.028

0.026

0.024

0.022

0.02

0.018

0.016

0.014

0.012

0.01

0.008

0.006

0.004

0.002

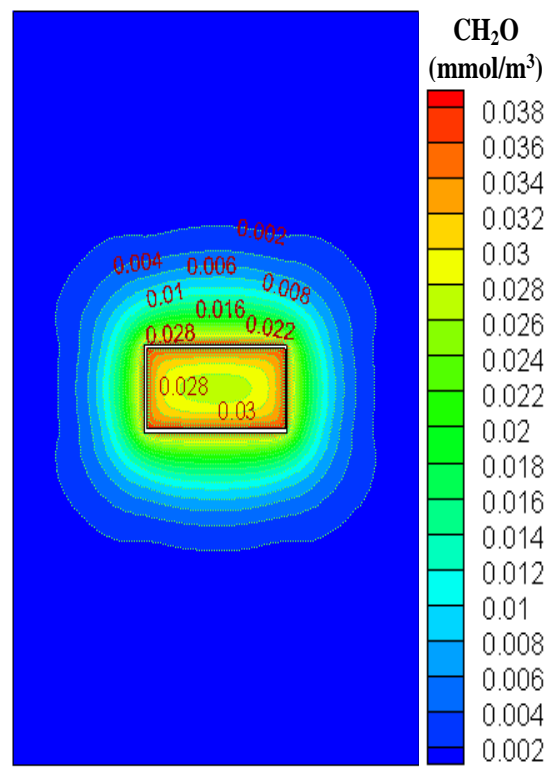

(a) Enclosed at z=0. 56m, $0.86 \mathrm{~m}, 0.995 \mathrm{~m}$

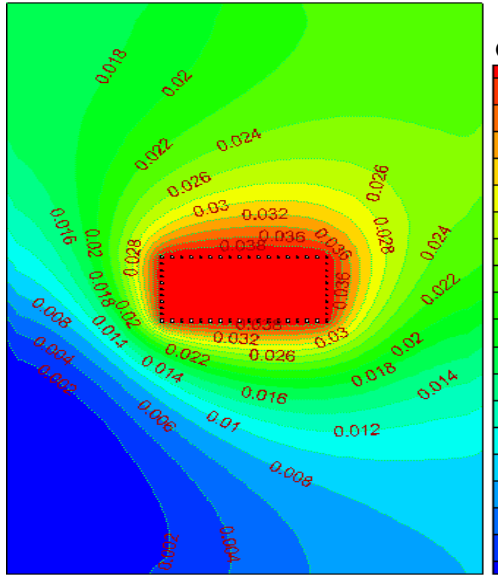

$\mathrm{CH}_{2} \mathrm{O}$ $\left(\mathbf{m m o l} / \mathbf{m}^{3}\right)$

0.038

0.036

0.034

0.03

0.028

0.026

0.024

0.022

0.02

0.018

0.016

0.014

0.012

0.01

0.008

0.006

0.004

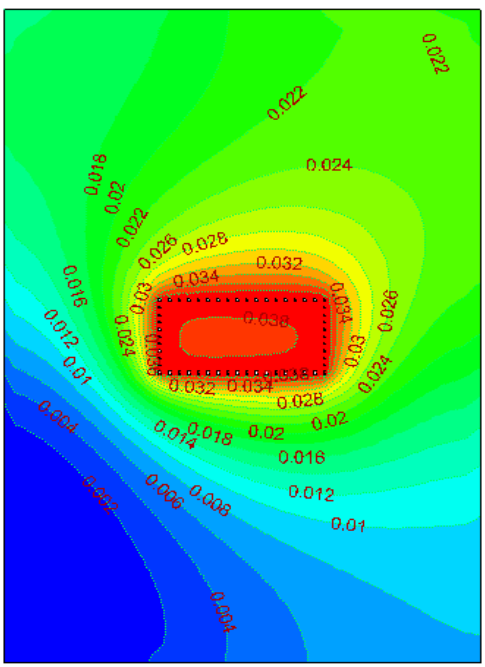

$\mathrm{CH}_{2} \mathrm{O}$

$\left(\mathbf{m m o l} / \mathrm{m}^{3}\right)$

0.038

0.036

0.034

0.032

0.03

0.028

0.026

0.024

0.022

0.02

0.018

0.016

0.014

0.012

0.01

0.008

0.006

0.004

0.002

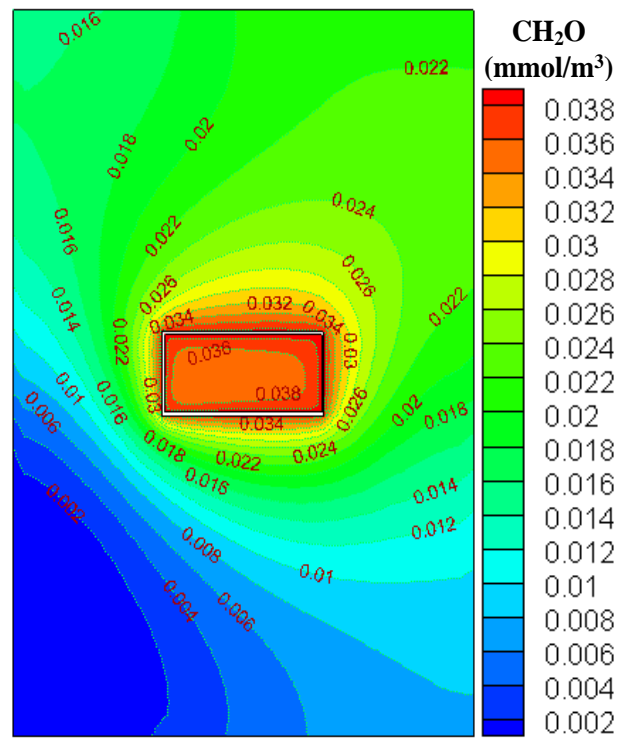

(b) Ventilation at $\mathrm{z}=0.56 \mathrm{~m}, 0.86 \mathrm{~m}, 0.995 \mathrm{~m}$

Figure 3. Formaldehyde concentration distribution at different height

When indoor ventilation, $\mathrm{CH}_{2} \mathrm{O}$ diffusion with romantic, thus the $\mathrm{CH}_{2} \mathrm{O}$ concentration increases in the downwind until 
spread to the entire interior, However, because of crib is the source of release of $\mathrm{CH}_{2} \mathrm{O}, \mathrm{CH}_{2} \mathrm{O}$ concentration in the vicinity is still high, especially in the inner side crib.

\section{Formaldehyde Concentration Distribution in Door Facade}

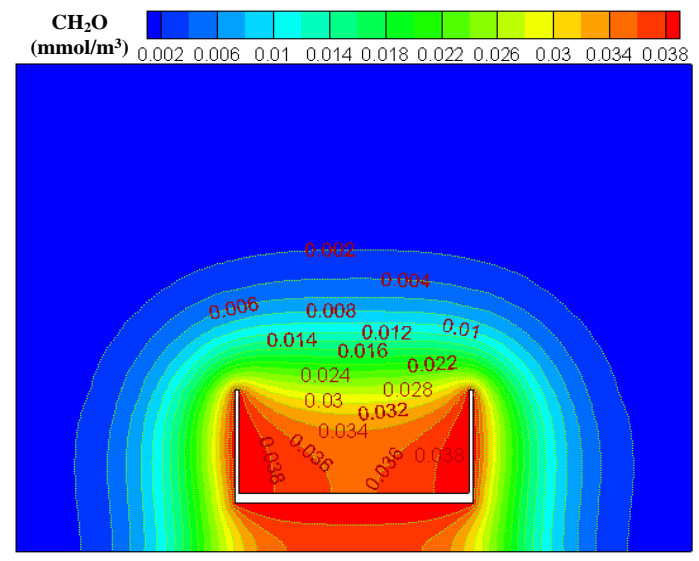

(a) Enclosed

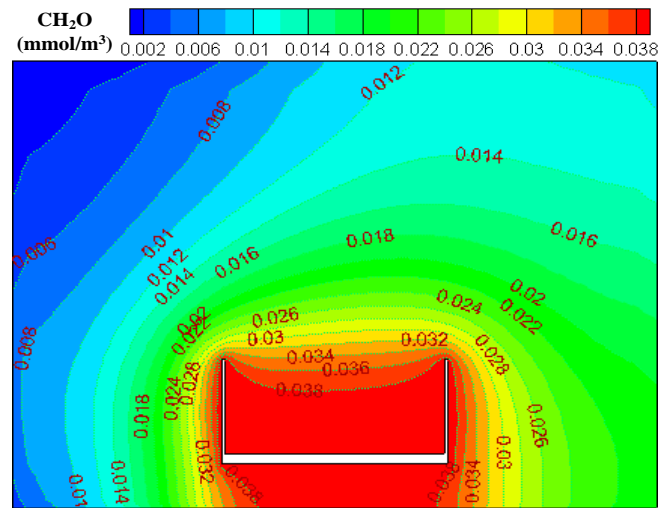

(b) Ventilation

Figure 4. Formaldehyde concentration distribution in the cross-section $\mathrm{y}=0 \mathrm{~m}$

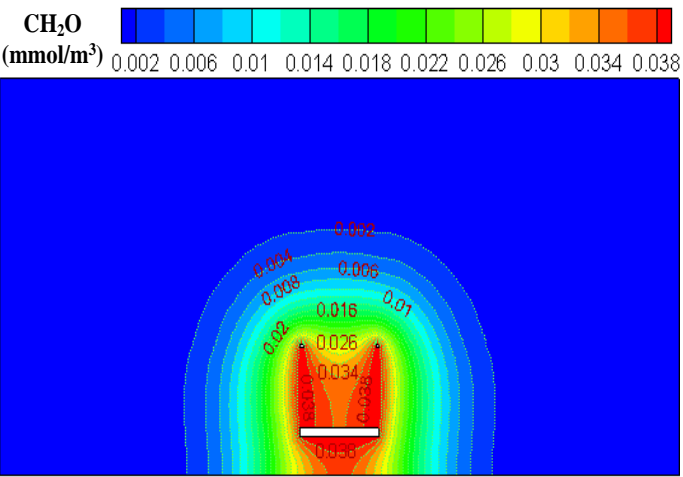

(a) Enclosed

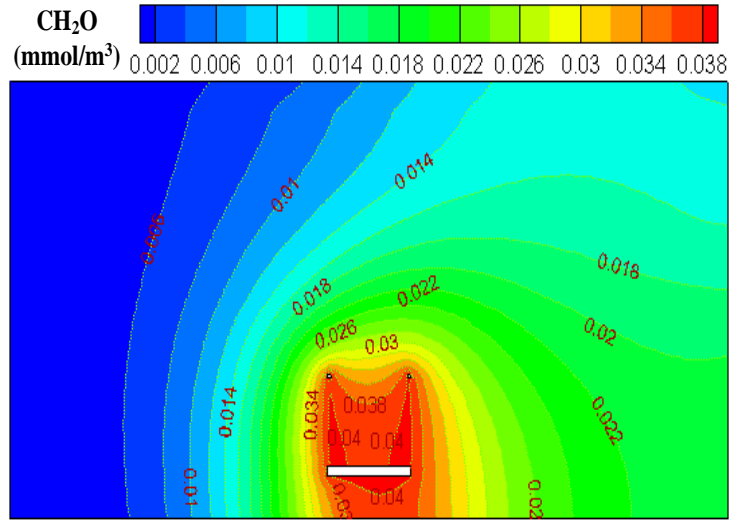

(b) Ventilation

Figure 5. Formaldehyde concentration distribution in the cross-section $\mathrm{x}=0 \mathrm{~m}$

Fig.4 and Fig.5 are vertical plane $\mathrm{CH}_{2} \mathrm{O}$ concentration contours when longitudinal and transverse interception cot body, from figure we can see, $\mathrm{CH}_{2} \mathrm{O}$ concentration in the inside and bottom of bed are higher. In closed indoor, the concentration outwardly from crib gradually reduced, but diffusion distance of $\mathrm{CH}_{2} \mathrm{O}$ is short. When indoor ventilation, $\mathrm{CH}_{2} \mathrm{O}$ diffusion strengthened, but $\mathrm{CH}_{2} \mathrm{O}$ concentration becomes smaller in inlet area, and downwind area becomes larger.

D. Comparison of Formaldehyde Concentration in Different Heights Inside Crib

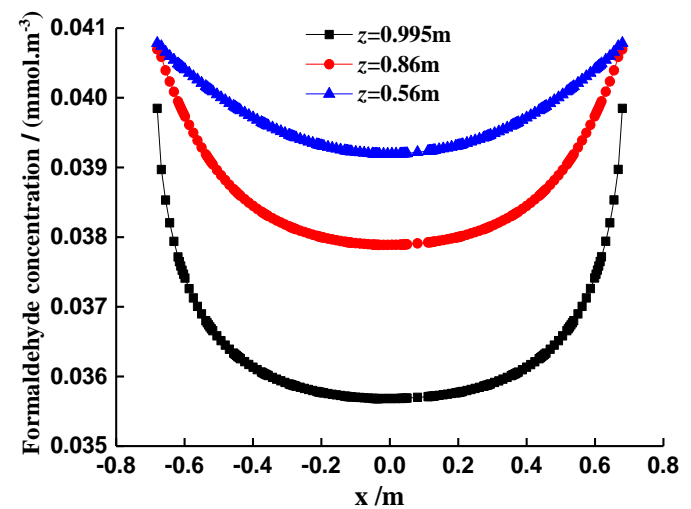

(a) Enclosed

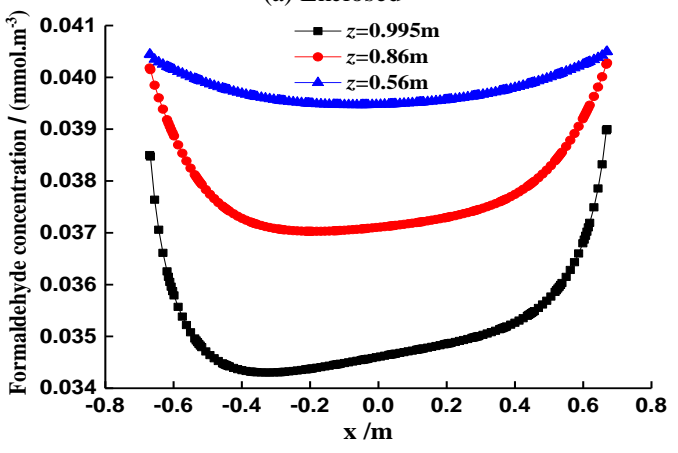

(b) Ventilation

Figure 6. Inside crib formaldehyde concentration at different heights 
Inside crib, along the longitudinal direction, examine distribution of $\mathrm{CH}_{2} \mathrm{O}$ concentration at different heights, obtained concentration of $\mathrm{CH}_{2} \mathrm{O}$ by numerical calculation in Figure 6. As can be seen from Fig.6, As the baby lying down, sitting and standing, the position height is increased, the concentration of $\mathrm{CH}_{2} \mathrm{O}$ has been reduced, but still has high concentration, Such as $\mathrm{z}=0.56 \mathrm{~m}, \mathrm{z}=0.86 \mathrm{~m}$ and $\mathrm{z}=0.995 \mathrm{~m}$, the $\mathrm{CH}_{2} \mathrm{O}$ concentrations in center were $0.03568 \mathrm{mmol} / \mathrm{m}^{3}$, $0.03789 \mathrm{mmol} / \mathrm{m}^{3}$ and $0.03919 \mathrm{mmol} / \mathrm{m}^{3}$, it is the standard $0.10 \mathrm{mg} / \mathrm{m}^{3}$ of Ministry of Public Health 10.7, 11.3, 11.7 times. When indoor ventilation, $\mathrm{CH}_{2} \mathrm{O}$ concentrations inside of the crib will be reduced, such as $\mathrm{z}=0.56 \mathrm{~m}, \mathrm{z}=0.86 \mathrm{~m}$ and $\mathrm{z}=0.995 \mathrm{~m}$, the minimum of $\mathrm{CH}_{2} \mathrm{O}$ were $0.03431 \mathrm{mmol} / \mathrm{m}^{3}$, $0.03703 \mathrm{mmol} / \mathrm{m}^{3}$ and $0.03907 \mathrm{mmol} / \mathrm{m}^{3}$, it is the standard $0.10 \mathrm{mg} / \mathrm{m}^{3}$ of Ministry of Public Health10.3, 11.1, 11.7 times.

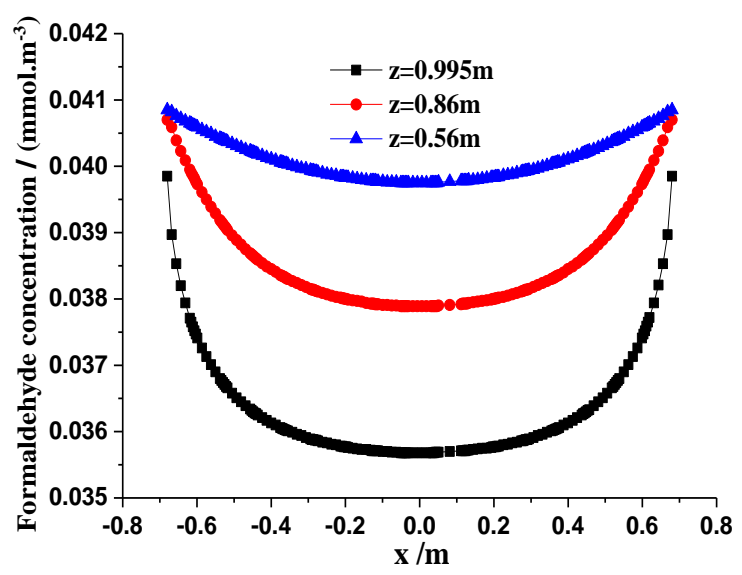

(a) Enclosed

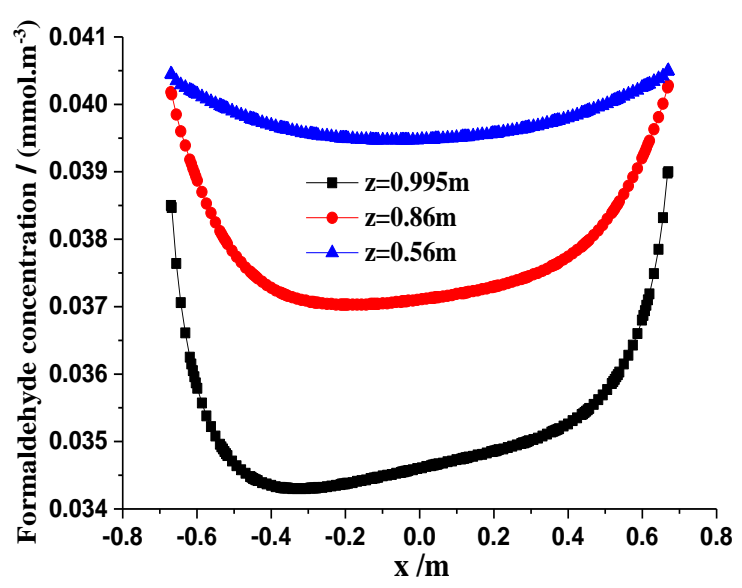

(b) Ventilation

Figure 7. Formaldehyde concentration inside crib as the room enclosed and ventilation.

Fig.7 reflects the change about concentration of $\mathrm{CH}_{2} \mathrm{O}$ in the inside of crib at different heights when the room was enclosed and ventilation. As can be seen from Fig.9, in ventilation, inside crib at different heights $\mathrm{CH}_{2} \mathrm{O}$ concentrations were reduced, and the below part of concentration of $\mathrm{CH}_{2} \mathrm{O}$ in cribs reduce is the most obvious. However, from the concentration changes of $\mathrm{CH}_{2} \mathrm{O}$, we can find that the ventilation can reduce the concentration of $\mathrm{CH}_{2} \mathrm{O}$ close to crib. If prolonged ventilation time, the release of $\mathrm{CH}_{2} \mathrm{O}$ strength will be weakened, and then strengthen the ventilation speed, will also reduce the $\mathrm{CH}_{2} \mathrm{O}$ concentration near crib.

\section{CONCLUSION}

This article by establishing $\mathrm{CH}_{2} \mathrm{O}$ release model of Crib, at room enclosed and ventilation conditions, numerical simulation of distribution about concentration of $\mathrm{CH}_{2} \mathrm{O}$ close to crib, calculations proves that $\mathrm{Crib} \mathrm{CH}_{2} \mathrm{O}$ concentration gradually decreases from bed to surrounding, and with increasing the height of baby lying down, sitting and standing position, the $\mathrm{CH}_{2} \mathrm{O}$ concentration decreases. In ventilation, the inside of crib at different heights for $\mathrm{CH}_{2} \mathrm{O}$ concentrations were reduced, and the below part of concentration of $\mathrm{CH}_{2} \mathrm{O}$ in cribs reduce is the most obvious. Ventilation enhanced diffusion of $\mathrm{CH}_{2} \mathrm{O}$, and the $\mathrm{CH}_{2} \mathrm{O}$ concentration becomes smaller in inlet area, and the downwind area becomes larger, but the inside of crib still has a high concentration of $\mathrm{CH}_{2} \mathrm{O}$ concentration. Compared $\mathrm{CH}_{2} \mathrm{O}$ concentration indoor confined conditions, $\mathrm{CH}_{2} \mathrm{O}$ diffusion is strengthened with indoor ventilation, and $\mathrm{CH}_{2} \mathrm{O}$ concentration in the crib interior is decreased at different height, If prolonged ventilation time, the release of $\mathrm{CH}_{2} \mathrm{O}$ strength will be weakened, and then strengthen the ventilation speed, will also reduce the $\mathrm{CH}_{2} \mathrm{O}$ concentration near crib. This study reveals theoretically indoor $\mathrm{CH}_{2} \mathrm{O}$ concentration distribution near crib, which has important practical significance to raise awareness of $\mathrm{CH}_{2} \mathrm{O}$ pollution and take some protective measures, in order to reduce harm caused by $\mathrm{CH}_{2} \mathrm{O}$ for infants.

\section{REFERENCES}

[1] Wang Gaochao, Chen Jun, Li Shuang. Interior decoration materials formaldehyde release Research Status and Development Trend [J]. Journal of Northwest Forestry University, 2014, 29(1): 188-191.

[2] Zhang Jian, Jiang Jinghui, Zhou Jin. Effect of panel products formaldehyde in indoor environment [J]. Wood Processing Machinery, 2003, 6: 9-11.

[3] Yang Jun, Cai Yu, Zhang Jingyan. Formaldehyde indoor distribution of major pollutants and impact assessment [J]. Inner Mongolia Environmental Protection, 2009, 21(4): 56-59.

[4] D.B McGregor, R.A Baan, C Partensky. E valuation of the carcinogenic risks to humans associated with surgical implants and other foreign bodies-bodies [J]. European Journal of Cancer, 2000, 36(3): 307-313.

[5] Cogliano V, Grosse Y, Baan R. Working group for meeting report: summary of IARC monographs on formaldehyde [J]. Environ Health Perspect, 2005, 88 (113): 1205-1208.

[6] Liu Fengyun, Sun Zheng, Zhang Xiaolei. Interior decoration pollution and children's respiratory health correlation analysis [J]. Modern Preventive Medicine, 2012, 39(13): 3195-3197.

[7] Wang Jinquan, Luo Jianzhong, Wenbi Yan. Advances in Study of indoor formaldehyde release [J]. Environment and Sustainable Development, 2006, 1: 24-26. 